Int. J. Dev. Biol. 55: 697-702

doi: $10.1387 / \mathrm{ijdb} .113422 \mathrm{mb}$

\title{
From the laboratory to the patient and back - an interview with Marc Mareel
}

\author{
MARC E. BRACKE* \\ Laboratory of Experimental Cancer Research, Department of Radiation Oncology and Experimental Cancer \\ Research, University Hospital, Ghent University, Ghent, Belgium
}

\begin{abstract}
The career of Marc Mareel is a synthesis of scientific research and clinical activity. During his medical studies, he already made his first enthusiastic steps in research via experimental work on avian developmental biology. Later, during his training as a radiotherapist, he founded his own laboratory for experimental cancer research. There he built up his international reputation as a pioneer in invasion research. Although invasion is the hallmark of tumor malignancy, he also kept an open mind about invasion in non-cancer conditions, such as in placental behavior, developmental biology, immunology and parasitology. His contribution to our understanding of invasion mechanisms has been both technical and conceptual. A number of assays have been developed in his lab, such as the embryonic chick heart and collagen gel invasion models, that have been (and still are) useful for many other research teams. He also contributed to the discovery of a number of key elements in the process of invasion, such as the stromal influence (including its extracellular matrix) and the cadherin family of cell-cell adhesion molecules. Concerning metastasis formation, he developed the original concept that a number of interacting eco-systems are implicated, such as the primary tumor, regional lymph nodes, the bone marrow and the (pre)metastatic niches in distant organs. Since his retirement, Marc Mareel has continued to integrate clinical practice with research creativity. He favours the idea of translational research bringing the results of laboratory findings to medical applications, and exploiting the feedback to the laboratory. The team in the Laboratory of Experimental Cancer Research at Ghent University currently consists of about 25 collaborators, who continue to appreciate his inspiring ideas and suggestions.
\end{abstract}

KEY WORDS: invasion, metastasis, mammary, ecosystem, translational research

Marc Mareel was born on September 18, 1938 in Lovendegem, a small village $10 \mathrm{~km}$ north-west of Ghent, where he spent his early childhood during the WW II occupation. He did his undergraduate Latin-Greek studies at the Sint-Lievenscollege in Ghent (1951-1957) and obtained his degree of Doctor of Medicine, Surgery and Obstetrics (1964) from the "Rijksuniversiteit Gent" (RUG), since 1991 named “Universiteit Gent" (UGent). He specialized in Radiotherapy and Nuclear Medicine (1971), and spent his entire career at the University of Ghent as Associate Professor (1983 - 1991) and as Professor of Oncology - Head of the Department of Radiotherapy and Nuclear Medicine at the University Hospital Ghent (1991 to 2003). Since October 2003 Marc Mareel is an Emeritus Professor, and since 2007 he serves as co-president of the Foundation against Cancer, a major fund-raising organism in Belgium.

Marc Mareel is internationally recognized as one of the pioneers in invasion and metastasis research with original contributions to methodology and to molecular mechanisms of these hallmarks of cancer malignancy. His current publications emphasize the ecosystem concept implicating a continuous interaction between cancer cells and tumor-associated host cells, and the effects of treatment on the "ecosystems of invasion and metastasis".

Professor Mareel, we know you as an internationally recognized pioneer of invasion and metastasis research. When and how did your interest in cancer research start?

In my third year as a medical student, I met with Prof. Lucien Vakaet (1926 - 1996), who was supervising the practical course of dissection at the Department of Anatomy, headed by Prof. Julien Fautrez (1914 - 1996) (Fig. 1). He "infected me with the virus of scientific research" as quoted in his interview by P. Van Gansen (1992). Vakaet was an internationally renowned avian embryologist. He not only permitted me to participate at his experiments

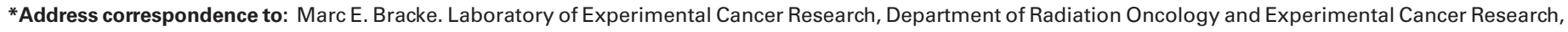
University Hospital 1P7, De Pintelaan 185, B-9000 Ghent, Belgium. Fax: +32-9-332-4991- e-mail: marc1.bracke@ugent.be
} 

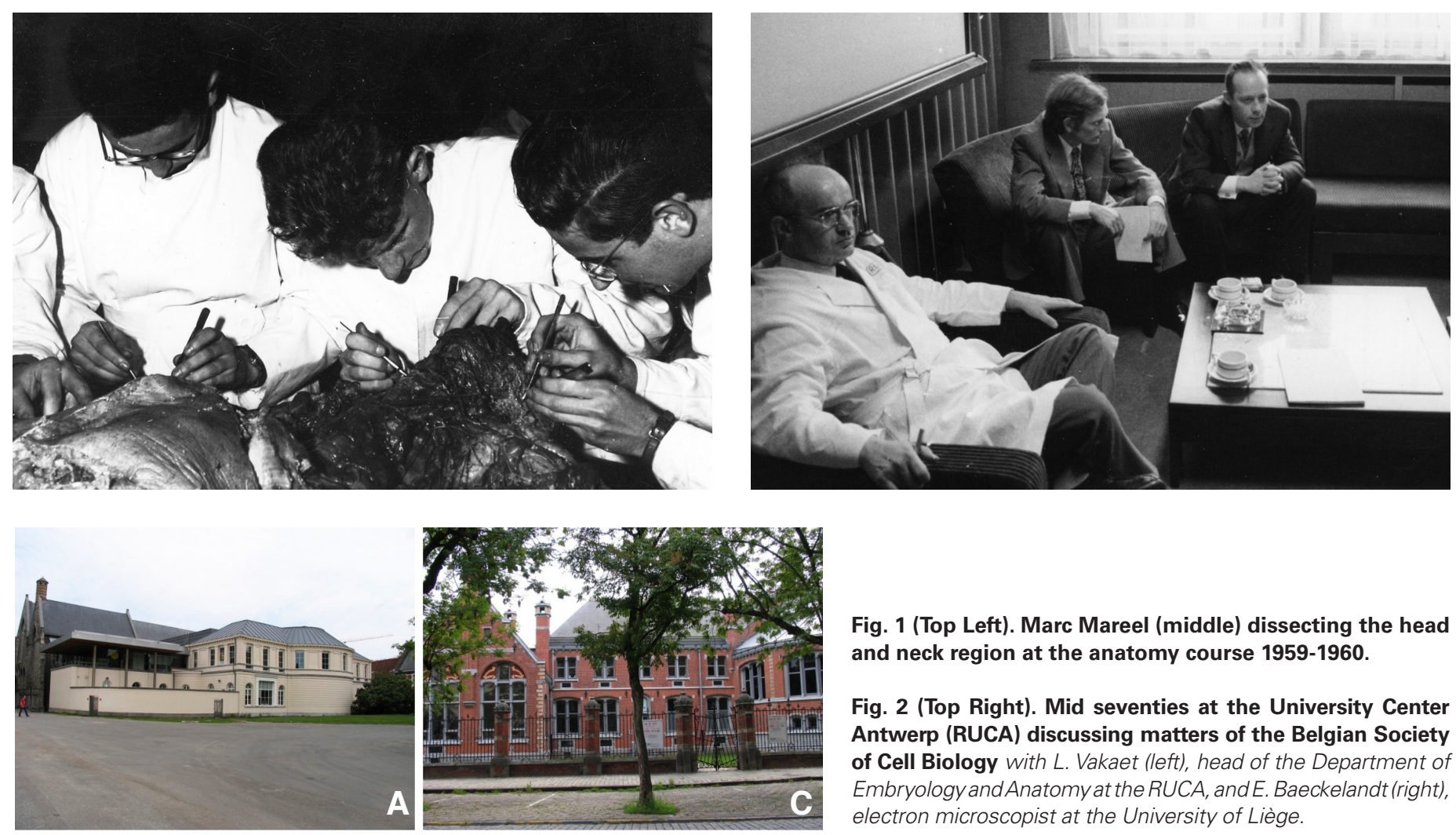

Fig. 1 (Top Left). Marc Mareel (middle) dissecting the head and neck region at the anatomy course 1959-1960.

Fig. 2 (Top Right). Mid seventies at the University Center Antwerp (RUCA) discussing matters of the Belgian Society of Cell Biology with L. Vakaet (left), head of the Department of Embryology and Anatomy at the RUCA, and E. Baeckelandt (right), electron microscopist at the University of Liège.
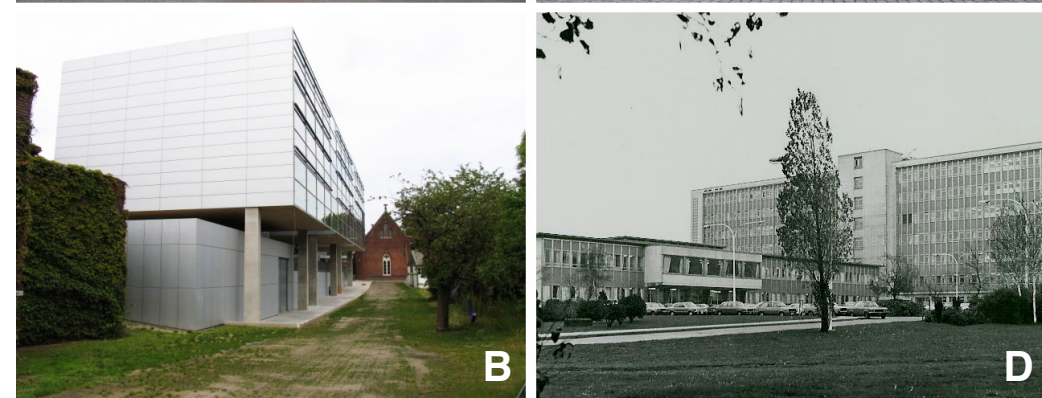

Fig. 3 (Left). Pictures tracing the locations of Marc Mareel's activities at the Ghent University. (A) The Anatomical Institute, nowa Music Center: first experiments at the laboratory of L. Vakaet (1960-1964). (B) The Department of Radiotherapy, now a concert hall (left), next to an apple garden with a few trees conserved (right) (1964-1969). Apples were not consumed because they were deemed to be radioactive. (C) Department of Ophthalmology at the Bijloke Hospital, where the Laboratory of Experimental Cancer Research found its first location (1964-1969). University clinical departments moved to the Heymans Campus in the sixties, and the Bijloke site is now used as a Museum, Music Center and High School. (D) The actual Department of Radiotherapy at the Campus Heymans, where the Laboratory of Experimental Cancer Research occupies the first floor of the lower building (left). Photographs were taken in 1972 (D) and August 2011 (A, B and C).

on early chick blastoderms (Vakaet and Mareel, 1964) but also provided me, as a student-assistent, with a salary that together with the generous support of my parents let me do research and study medicine during 4 years without financial concern. L.Vakaet had brought the organotypic culture technique to Ghent from his stay at the Laboratory of Prof. E. Wolff in Strasbourg (1955). When one of my fellow students decided to leave research for full time clinical work, L. Vakaet passed to me the project on development of the embryonic chick tibia in organ culture (Mareel, 1967). The results won me a journey to the Chester Beatty Research Institute, London, where I worked with G. and D. Easty, pioneers in cancer invasion research (Easty and Easty, 1963), and with J. Ambrose, a physicochemist with great interest in cancer cell biology. Under L. Vakaet, I also did the research for my "Aggregaat Hoger Onderwijs", a PhD equivalent, about transplantation of cancer cells into young chick blastoderms (1972), a quite obvious combination of his interest in early bird embryology and my unexplained wish to do cancer research. (Fig. 2)
This clarifies indeed your genuine interest in experimental cancer studies, but still I wonder how your research and your clinical activities are related to each other.

After my medical degree (1964), I wanted to do cancer research, yet keeping close contact with clinical oncology. A good advice came, again, from L. Vakaet. "Look for a place at the University Hospital where the Head of Department allows such combination and provides space and money to start your own laboratory"he spelled out. That is exactly what I found at the department of Radiotherapy and Nuclear Medicine (Director, Prof. dr. P. M. Van Vaerenbergh, 1904 - 1977). So, my choice for Radiotherapy as a profession was not primarily inspired by a genuine interest in this discipline per se. After one year, L. de Ridder joined the effort and together we have built the Laboratory of Experimental Cancer Research, first at the Bijloke site and later at the Campus Heymans, until he left to become a Professor of Histology at our University (Fig. 3).

During my entire career I have combined experimental cancer research and clinical radiotherapy-oncology with great satisfac- 
tion. I spent the last decade of my career (1991 - 2003) as Head of the Department of Radiotherapy and Nuclear Medicine at the University Hospital Ghent, without giving up my research activities. To the contrary, this was an occasion to put emphasis on research in the clinical Department by engaging two colleagues with great interest in translational research to lead the clinical activities in Radiotherapy (W. De Neve) and Nuclear Medicine (R. Dierckx) at academic level, and by preaching research as a basis for clinical decisions every morning at the clinical staff meeting.

Had I ever been obliged to choose between research and clinical activity there is not the shadow of a doubt about my preference for the laboratory, neither today nor in the past. Though, I am convinced that it was, and still is, not too difficult to find good places where you can combine both.

There are many examples of medical doctors who have combined research and clinical practice. To give just two examples. Prof. J.-M. Foidart from the Université de Liège, is closely related to mammary cancer. He and his students are practicing gynecologists who have contributed greatly to our understanding of basic mechanisms of cancer metastasis and they and their school continue to do so. My second example, Prof. G. Storme, is one of my first students. He has built at the VUB (Flemish University Brussels) one of the most advanced radiotherapy departments, performing clinical work at the highest academic level. It gives me great pleasure that his department harbours a research laboratory that yielded valuable contributions to the molecular understanding of hypoxia-related radioresistance.

At the age of my pension (2003), I was lucky enough to get the opportunity to continue my double activity but now without the burden of all the administrative work that is the privilege of a Head of Department. As a result, my second paper in clinical radiotherapy appeared 3 years ago (Veldeman et al., 2008), 40 years after my first one (Mareel and Van Vaerenbergh, 1968). My latest research paper is about the effects of ionizing radiation on invasion and metastasis in a murine model of metastatic mammary cancer (Vala et al., 2010); it gave me as much satisfaction as my first research paper, almost 50 years ago.

You mentioned your special interest in the effects of ionizing radiation on invasion and metastasis. What were the other major topics in your cancer research?

After my PhD thesis on chick blastoderm transplantations (Mareel et al., 1975), I turned my attention to models of invasion in vitro and in vivo that were closer to reality. Much attention was paid to invasion in organ culture, a technique that I learned as a student. E. Wolff used embryonic tissue, mostly mesonephros, as a source of growth factors for human cancer cells. For subculturing and expanding the cancercell population, he separated the mesonephros from the cancer cells by a piece of vitelline membrane. Removing the membrane brought cancer cells into direct contact with the normal tissue and so provided us with a model for invasion (de Ridder et al., 1977).

The aim of my research was, and still is, understanding the mechanisms of cancer invasion and metastasis. Within this topic, the direction of my research has been very much influenced by contact with other researchers inside or outside the laboratory (Fig. 4).

An encounter with Marc De Brabander (1943 - 2011), working at Janssen Pharmaceutica in Beerse, Belgium, brought microtubule inhibitors into the laboratory as powerful inhibitors of invasion (Mareel and De Brabander, 1978). Translation into therapy was, however, hampered by the fact that antiinvasive doses of these drugs were also cytotoxic.

Your (Marc Bracke) arrival introduced extracellular matrix with emphasis on cartilage because it appeared to be resistant to invasion (Bracke etal., 1984) and basement membrane matrix because it distinguished between invasive and noninvasive cells. Later, you also introduced a specific interest for hormonal influences on

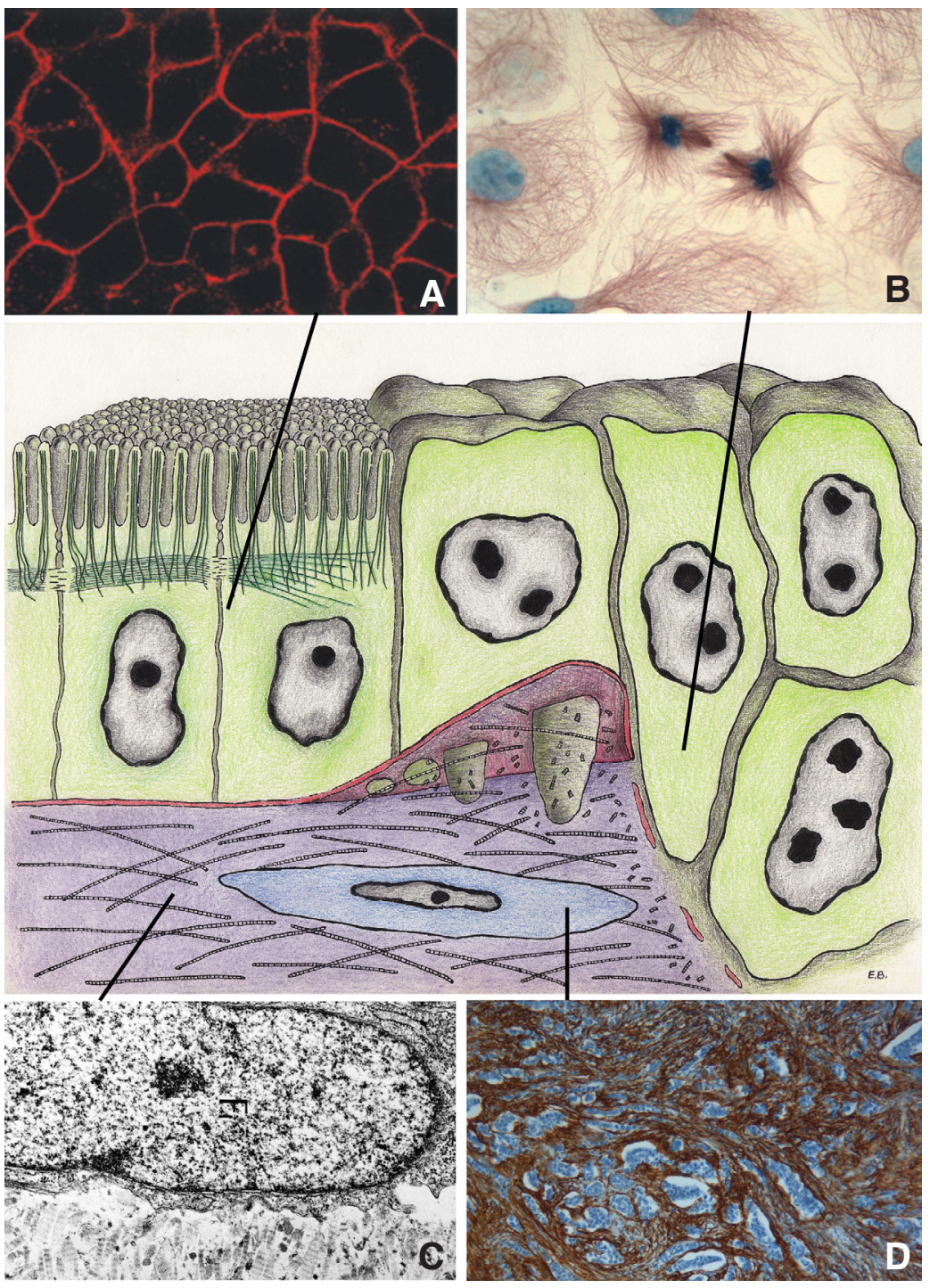

Fig. 4. Some major topics developed in the Laboratory of Experimental Cancer Research. The central naive cartoon covers different aspects of invasion during cancer progression (to be read from left to right). (A) Immunocytochemical staining of the cell-cell adhesion molecule E-cadherin in epithelioid cells in culture. (B) Immunocytochemical staining of the cytoplasmic microtubule complex, which is crucial for directional migration. (C) Transmission electron micrograph of a confronting culture, illustrating the resistance of the cartilaginous extracellular matrix to cellular invasion. (D) Immunohistochemical staining of alpha smooth muscle actin, showing the abundance of myofibroblasts in a breast carcinoma. 
breast cancer cell invasion (Bracke et al., 1994), and you still use our original chick heart invasion model (Mareel et al., 1979) for the screening of drugs in vitro (Katritzky et al., 2006).

Walter Fiers, Professor of Biochemistry at our University, persuaded me to look at the role of oncogenes in invasion and introduced me to his PhD student Frans van Roy. This resulted in a long and very fruitful collaboration first on oncogenes (Van Roy et al., 1986) and thereafter on the cell-cell adhesion molecule E-cadherin (Vleminckx et al., 1991), that we characterized as an invasion-suppressor gene product, regulated at various levels (Mareel et al., 1991; Vermeulen et al., 1995; Comijn et al., 2001). I broughtE-cadherin to Ghent after a meeting with Walter Birchmeier in the late eighties (Behrens et al., 1989). There are two other topics that I have tackled with great enthusiasm: one, the invasive and metastatic characteristics of micro-organisms as compared to metastatic cancer cells; two, the crucial role of tumor-associated host cells in cancer invasion. The first topic was inspired by a meeting in the vicinity of Lugano, co-organized by Philippe Sansonetti from the Pasteur Institute in Paris and materialized by two brilliant students who worked on Entamoeba histolytica (Leroy et al., 2000) and on Listeria monocytogenes (Oliveira et al., 2003). The other topic was on my mind since Patrick De Baetselier reported results from his work at the Weizmann Institute in Rehovot, Israel, showing that normal B-lymphocytes could convey metastatic capability upon plasmocytoma cells (De Baetselier et al., 1981). Experiments started when François Martin, an immunologist from Dijon, France, asked us to characterize some of his rat colon cancer cell lines in our invasion models. It appeared that none of these cancer cells were invasive unless myofibroblasts were added to the system (Dimanche-Boitrel et al., 1994). Since, tumor-associated host cells are a major topic in our laboratory (De Wever et al., 2004; De Wever et al., 2008). To summarize, I think that we have contributed some valuable pieces to the puzzle, though the question when, why and how cancer does metastasize remains unanswered. My actual way of thinking about this problem follows the ecosystem concept (Mareel and Constantino, 2011).

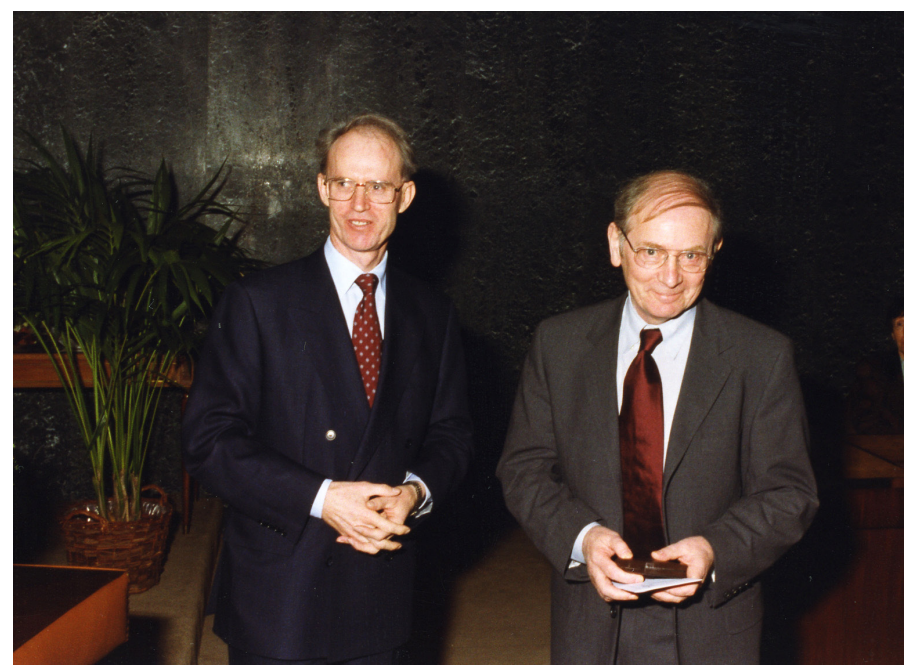

Looking at the impressive publication list from your lab, I was struck by the high number of papers on mammary cancer. Yet, you did not mention mammary cancer as one of your favorite topics. Why is that?

Since there is, as yet, no good evidence to accept that the mechanisms of invasion and metastasis are fundamentally different in breast cancer as compared to most other epithelial cancers, I have not focused my research on any particular cancer type. Nevertheless, mammary cancer has crossed my path many times indeed. In the laboratory these encounters were due to the choice of appropriate material, tumors or cell lines, for a given experiment and to the interest of some collaborators in the hormonal aspects of breast cancer. In the clinic, they were the consequence of the high frequency of breast cancer and the indispensable place of radiotherapy in its treatment. Searching PubMed for "Mareel M AND breast cancer" yields 37 papers, the first - one of my rare clinical papers - in 1968 (Mareel and Van Vaerenbergh, 1968) and the latest - covering my new interest in ionizing radiation and invasion - in 2010 (Vala et al., 2010). The breast cancer link is mainly through the choice of cell lines like MCF-7. An additional search for "Mareel M AND mammary gland" reveals 6 more papers in which the normal murine mammary gland cell family, coined NMuMG, plays a major role. One of these papers is my most cited one (Vleminckx et al., 1991, cited 1,107 times) (Fig. 5).

\section{Let me ask you a question that applies to mammary cancer} more specifically: have you observed advances in its treatment since the start of your medical career?

Beyond the shadow of a doubt, yes, treatment of breast cancer has improved substantially. Side effects of all forms of treatment have decreased and cure rate has increased. Today, locoregional control under very acceptable conditions is achieved in most patients, distant metastasis being the cause of death in those patients that die from their disease, a serious motivation for my research.

My contact with breast cancer started in the early sixties, when I was a medical student. Then, all patients underwent extensive

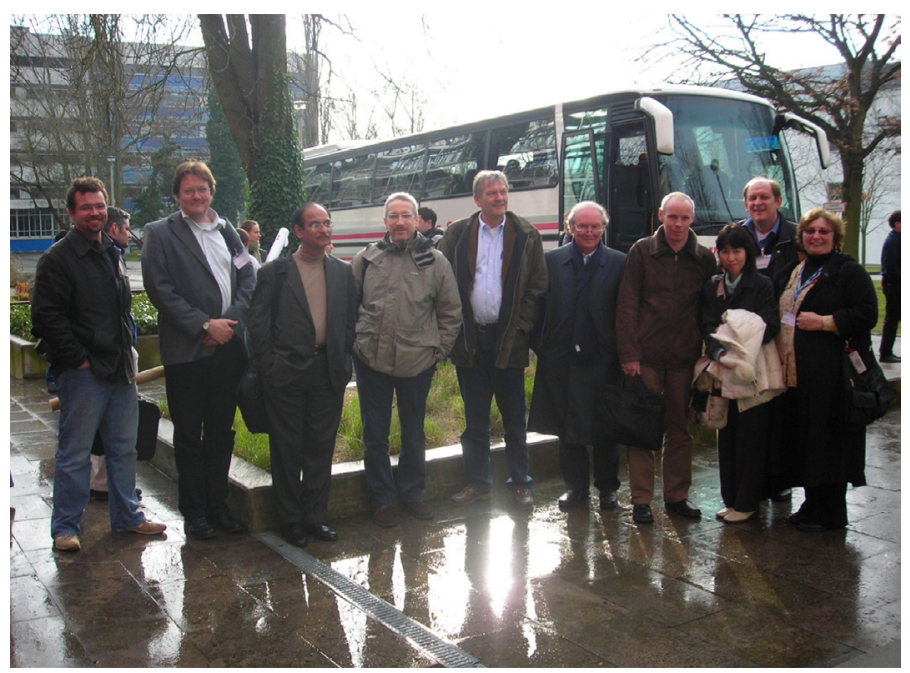

Fig. 5 (Left). Sidmar award 1998 ceremony at the Royal Belgian Academy of Medicine in Brussels. Marc Mareel (right) receives the award from Hedwig Vergote (left).

Fig. 6 (Right). Spring 2008. International Conference "Invasion and Metastasis" at the Max Delbrück Center for Molecular Medicine in Berlin Buch organized by Walter Birchmeier and Jürgen Behrens. 


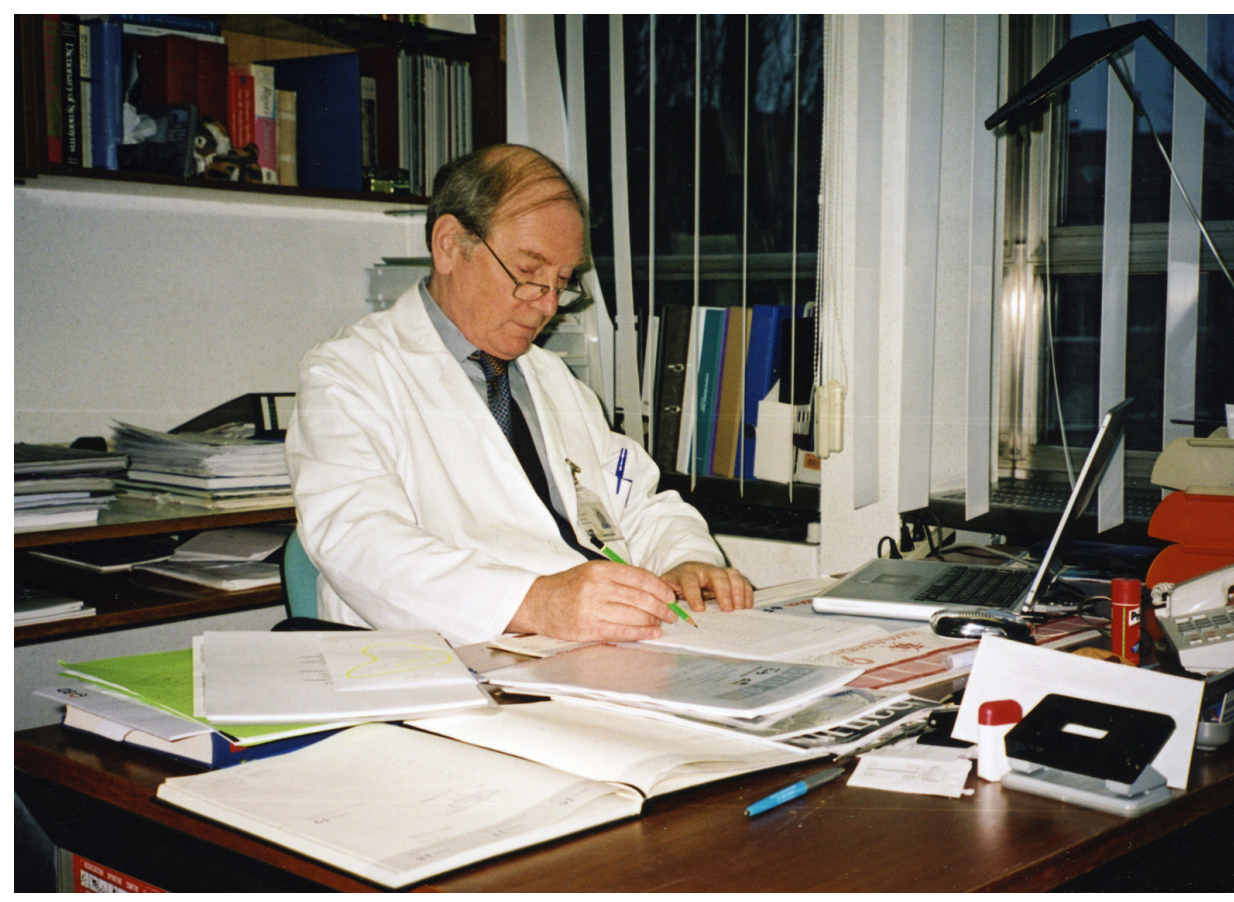

Fig. 7. Marc Mareel in his office at the Laboratory of Experimental Cancer Research, University Hospital Ghent (2009).

surgery through the procedure launched by William Steward Halsted around 1880. It consisted in resection of the whole breast, including pectoralis muscles and as much of the axillary lymph nodes as feasible. The fact that this mutilating procedure persisted for almost one century is easily understood as it heralded a cure rate of $50 \%$ for a disease that, before Halsted, killed most of the patients. In the seventies much more limited surgery with removal of the tumor only and diagnostic exploration of the axilla started to replace the Halsted procedure, which was abandoned completely after publication of high level evidence from clinical trials comparing mastectomy with tumorectomy plus radiotherapy. The biological basis for this change was launched by Georges Crile (1950s) and Bernard Fisher (1970s), stating that breast cancer is a systemic disease and that the seeds of metastasis have escaped already at the moment of surgery rather than a locoregional disease that can be removed before it spreads. This statement is confirmed by all experimental and clinical evidence published since. Added to locoregional treatment is adjuvant chemotherapy and hormonotherapy. The latter was initiated by George Thomas Beatson performing oophorectomy at the end of the nineteenth century and later extended with adrenalectomy and hypophysectomy. These debilitating procedures were replaced in the eighties by the estrogen receptor antagonist tamoxifen, an oral drug with few side effects and quite good results in patients with tumors expressing estrogen receptors. In the same period, bisphosphonates were introduced in the clinic: they are inhibitors of osteoclasts and useful for the palliative treatment of bone metastasis. Determination of estrogen receptors is an early example of selection of patients for treatment on the basis of molecular tumor characteristics. More recently, routine determination of hormone receptors was added with measurement of the growth factor tyrosine kinase receptor c-ErbB2 (HER-2/neu) for selection of patients that possibly respond to the monoclonal antibody Herceptin (trastuzumab). The last decade has seen an explosion of genetic and genomic findings that await translation into preventive, diagnostic and therapeutic practice. A serious obstacle for this most interesting translational project is financial support for independent academic research. The National Cancer Plan, installed in 2007, constitutes an invaluable initiative to tackle this problem (Fig. 6).

Taking into consideration your large scientific and clinical experience, I would like to forward my final question: in what direction would you like cancer research to evolve?

Today, translational research is rightly much emphasized; there are myriads of laboratory results that await clinical application. If I would start working on breast cancer, I would go for distinction between metastatic and nonmetastatic tumors with focus on inflammation, circulating tumor cells and bone marrow responses, with the aim to restrict systemic therapy to subgroups of patients. Within the latter cohort, I would attempt to individualize treatment and evaluate responses during the treatment on the basis of molecular characterization of the tumor before and during treatment.

I am, nevertheless, firmly convinced that we cannot afford reducing support for fundamental research. For, it might well be that the fundamental discovery that will lead to full understanding and successful treatment of cancer remains to be made (Fig. 7).

\section{References}

BEHRENS, J., MAREEL, M. M., VAN ROY, F. M. and BIRCHMEIER, W. (1989). Dissecting tumor cell invasion: epithelial cells acquire invasive properties following the loss of uvomorulin-mediated cell-cell adhesion. J Cell Biol 108: 2435-2447.

BRACKE, M. E., VAN CAUWENBERGE, R. M., MAREEL, M. M. (1984). Interaction of malignant cells with salt-extracted cartilage in vitro. Cancer Res 44: 297-304.

BRACKE, M. E., CHARLIER, C., BRUYNEEL, E. A., LABIT, C., MAREEL, M. M. and CASTRONOVO, V. (1994). Tamoxifen restores the E-cadherin function in human breast cancer MCF-7/6 cells and suppresses their invasive phenotype, Cancer Res 54: 4607-4609.

BRACKE, M. E., DEPYPERE, H. T., BOTERBERG, T., VAN MARCK, V. L., VENNEKENS, K. M., VANLUCHENE, E., NUYTINCK, M., SERREYN, R. and MAREEL, M. M. (1999) Influence of tangeretin on tamoxifen's therapeutic benefit in mammary cancer, J Natl Cancer Inst 91: 354-359.

COMIJN, J., BERX, G., VERMASSEN, P., VERSCHUEREN, K., VAN GRUNSVEN L., BRUYNEEL, E., MAREEL, M., HUYLEBROECK, D. and VAN ROY, F. (2001) The two-handed $E$ box binding zinc finger protein SIP1 downregulates E-cadherin and induces invasion. Mol Cell 7: 1267-1278.

DE BAETSELIER, P., GORELIK, E., ESHAR, Z., RON, Y., KATZAV, S., FELDMAN M. and SEGAL, S. (1981). Metastatic properties conferred on nonmetasatic tumors by hybridization of spleen B-lymphocytes with plasmocytoma cells. J Natl Cancer Inst 67: 1079-87.

DE RIDDER, L., MAREEL, M. and VAKAET, L. (1977). Invasion of malignant cells into cultured embryonic substrates. Arch Geschwulstforsch 47: 7-27.

DE WEVER, O., NGUYEN, Q.-D., VAN HOORDE, L., BRACKE, M., BRUYNEEL, E., 
GESPACH, C. and MAREEL, M (2004). Tenascin-C and SF/HGF produced by myofibroblasts in vitro provide convergent pro-invasive signals to human colon cancer cells through RhoA and Rac. FASEB J 18: 1016-1018.

DE WEVER, O., DE METTER, P., MAREEL, M. and BRACKE, M. (2008). Stromal myofibroblasts are drivers of invasive cancer growth. Int J Cancer 123: 2229-38.

DIMANCHE-BOITREL, M. T., VAKAET, L., PULUGUET, P., CHAUFFERT, B., MARTIN, M. S., HAMANN, A., VAN ROY, F., MAREEL, M., MARTIN, F. (1994). In vivo and in vitroinvasiveness of a rat colon-cancer cell line maintaining $E$-cadherin expression: an enhancing role of tumor-associated myofibroblasts. Int J Cancer 56: 512-21.

EASTY, G. C. and EASTY, D. M. (1963). An organ culture system for the examination of tumor invasion. Nature 199: 1104-1105.

KATRITZKY, A. R., KUANAR, M., DOBCHEV, D. A., VANHOECKE, B. W., KARELSON, M., PARMAR, V. S., STEVENS, C. V. and BRACKE, M. E. (2006). QSAR model of anti-invasive activity of organic compounds using structural descriptors. Bioorg Med Chem 14: 6933-6939.

LEROY, A., LAUWAET, T., DE BRUYNE, G., CORNELISSEN, M. and MAREEL, M. (2000). Entamoeba histolytica disturbs the tight junction complex in human enteric T84 cell layers. FASEB $J 14,1139-1146$.

MAREEL. M. (1967). Recherches sur la relation inductrice entre chondrocytes et périoste dans le tibia embryonnaire de poulet. Arch Biol (Liège) 78: 145-166.

MAREEL, M. and VAN VAERENBERGH, P. M. (1968). Mammacarcinoom na bestraling. J Belge Radiol 51: 348 - 350.

MAREEL, M., DE RIDDER, L., DE BRABANDER, M., BOZZI, A. and VAKAET, L. (1975) Characterization of spontaneous, chemical and viral transformants of a $\mathrm{C} 3 \mathrm{H} / 3 \mathrm{~T} 3$-type mouse cell line by transplantation into young chick blastoderms. $\checkmark$ Natl Cancer Inst 54: 923-9.

MAREEL, M., KINT, J. and MEYVISCH, C. (1979) Methods of study of the invasion of malignant $\mathrm{C} 3 \mathrm{H}$-mouse fibroblasts into embryonic chick heart in vitro. Virchows Arch B: Cell Pathol Incl Mol Pathol 30: 95-111.

MAREEL, M. M. and DE BRABANDER, M. (1978) Effect of microtubule inhibitors on maligant invasion in vitro. J Natl Cancer Inst 61: 787-792.

MAREEL, M. M., BEHRENS, J., BIRCHMEIER, W., DE BRUYNE, G. K., VLEMINCKX,
K., HOOGEWIJS, A., FIERS, W. C. and VAN ROY, F. M. (1991). Downregulation of E-cadherin expression in Madin Darby canine kidney (MDCK) cells inside nude mice tumors. Int J Cancer 47: 922-928.

MAREEL, M. and CONSTANTINO, S. (2011) Ecosystems of invasion and metastasis in mammary morphogenesis and cancer. Int. J. Dev. Biol. 55 (doi: 10.1387/ ijdb.113386mm)

OLIVEIRA, M. J., VAN DAMME, J., LAUWAET, T., DE CORTE, V., DE BRUYNE, G., VERSCHRAEGEN, G., VANEECHOUTTE, M., GOETHALS, M., AHMADIAN, M. R., MÜLLER, O., VANDEKERCKHOVE, J., MAREEL, M. and LEROY, A. (2003). $\beta$-casein-derived peptides, produced by bacteria, stimulate cancer cell invasion and motility, EMBO J 22: 6161-6173.

VAKAET, L. and MAREEL, M. (1964). Quelques précisions sur la régénération de l'endoblaste du blastoderme de poulet. C R Soc Biol 157: 902-903.

VALA, S., MARTINS, L. R., IMAIZUMI, N., NUNES, R. J., RINO, J., KUONEN, F., CARVALHO, L. M., RUEGG, C., GRILLO, I. M., BARATA, J.T., MAREEL, M. and SANTOS, S. C. (2010). Low doses of ionizing radiation promote tumor growth and metastasis by enhancing angiogenesis. PLOS One 5: e11222.

VAN GANSEN, P. (1992) Lucien Vakaet, an avian embryologist. Int J Dev Biol 36: 43-45.

VAN ROY, F., MESSIAEN, L., LIEBAUT, G., GAO, J., DRAGONETTI, C. H., FIERS, W. and MAREEL, M. (1986). Invasiveness and metastatic capability of rat fibroblast-like cells before and after transfection with immortalizing genes. Cancer Res 46: 4787-4795.

VELDEMAN, L., MADANI, I., HUSTAERT, F., DE MEERLEER, G., MAREEL, M. and DE NEVE, W. (2008) Evidence behind use of intensity-modulated radiotherapy: a systematic review of comparative clinical studies. Lancet Oncol 9: 367- 375.

VERMEULEN, S. J., BRUYNEEL, E. A., BRACKE, M. E., DE BRUYNE, G. K., VEN NEKENS, K. M., VLEMINCKX, K. L., BERX, G. J., VAN ROY, F. M. and MAREEL, M. M. (1995). Transition from the noninvasive to the invasive phenotype and loss of alpha-catenin in human colon cancer cells. Cancer Res 55: 4722-4728.

VLEMINCKX, K., VAKAET, L. JR, MAREEL, M., FIERS, W. and VAN ROY, F. (1991) Genetic manipulation of E-cadherin expression by epithelial tumor cells reveals an invasion suppressor role. Cell 66: 107-119. 


\section{Further Related Reading, published previously in the Int. J. Dev. Biol.}

See our Special Issue Invasion in Cancer and Embryonic Development edited by Marc Mareel and Juan Aréchaga at: http://www.ijdb.ehu.es/web/contents.php?vol=48\&issue=5-6

Modeling and quantification of cancer cell invasion through collagen type I matrices

Olivier De Wever, An Hendrix, Astrid De Boeck, Wendy Westbroek,Geert Braems, Shahin Emami, Michèle Sabbah, Christian Gespach and Marc Bracke

Int. J. Dev. Biol. (2010) 54: 887-896

Germinal tumor invasion and the role of the testicular stroma

Alejandro Díez-Torre, Unai Silván, Olivier De Wever, Erik Bruyneel, Marc Mareel and Juan Aréchaga

Int. J. Dev. Biol. (2004) 48: 545-557

Molecular cell biology and cancer metastasis. An interview with Garth Nicolson Marc Mareel

Int. J. Dev. Biol. (2004) 48: 355-363

Molecular aspects of cancer metastasis: extracellular regulation of the E-cadherin/ catenin complex

M Mareel, T Boterberg, V Noë, E Bruyneel and M Bracke

Int. J. Dev. Biol. (1996) 40: S65-S67

Expression of E-cadherin in embryogenetic ingression and cancer invasion M Mareel, M Bracke, F Van Roy and L Vakaet

Int. J. Dev. Biol. (1993) 37: 227-235

5 yr ISI Impact Factor $(2010)=2.961$

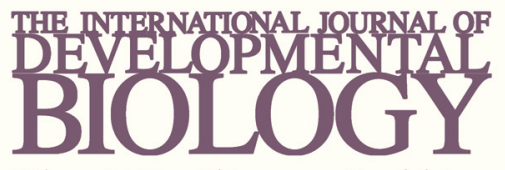

Volume 54 Nos. $6 / 7$
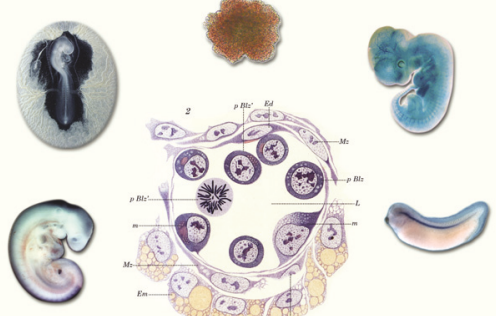

evelopmenta1 Hematopoiesis

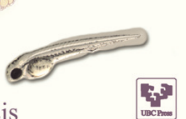

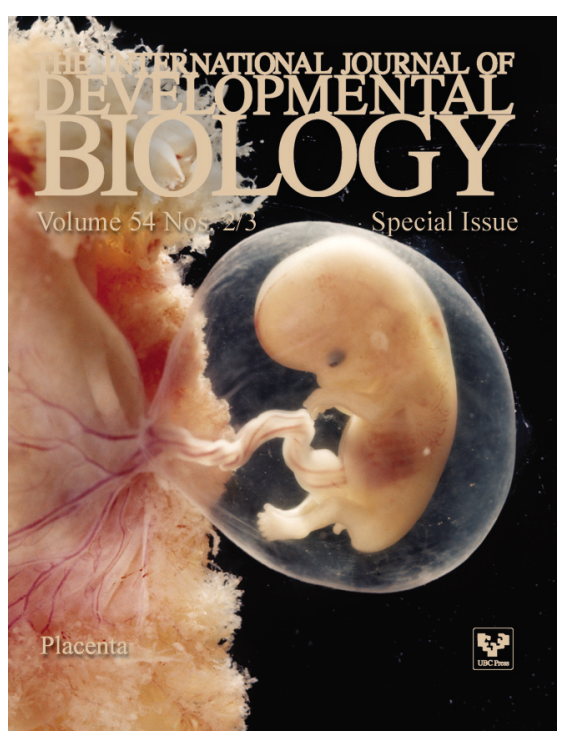
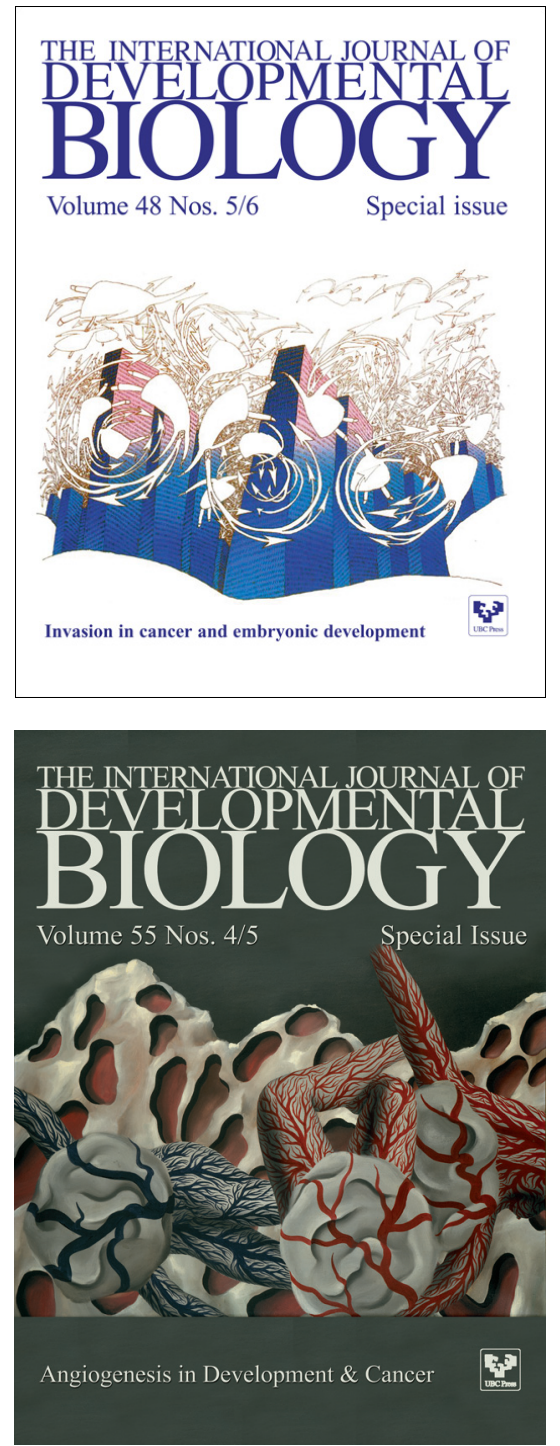